\title{
Combining charcoal and elemental black carbon analysis in sedimentary archives: Implications for past fire regimes, the pyrogenic carbon cycle, and the human-climate interactions
}

\author{
Florian Thevenon ${ }^{\mathrm{a}, *}$, David Williamson ${ }^{\mathrm{b}}$, Edouard Bard ${ }^{\mathrm{b}}$, Flavio S. Anselmetti ${ }^{\mathrm{c}}$, \\ Luc Beaufort ${ }^{\mathrm{b}}$, Hélène Cachier ${ }^{\mathrm{d}}$ \\ ${ }^{a}$ F.-A. Forel Institute, University of Geneva, 1290 Versoix, Switzerland \\ b CEREGE/CNRS Université Aix-Marseille 3, BP 80, 13545 Aix-en-Provence Cedex 04, France \\ c Eawag, Swiss Federal Institute of Aquatic Science and Technology, 8600 Dübendorf, Switzerland \\ d Laboratoire des Sciences du Climat et de l'Environnement, Gif surYvette, France
}

\section{A R T I C L E I N F O}

Article history:

Accepted 13 December 2009

Available online 18 January 2010

\section{Keywords:}

biomass burning

carbon cycle

charcoal

black carbon

climate

human impact

\begin{abstract}
A B S T R A C T
This paper addresses the quantification of combustion-derived products in oceanic and continental sediments by optical and chemical approaches, and the interest of combining such methods for reconstructing past biomass burning activity and the pyrogenic carbon cycle. In such context, the dark particles $>0.2 \mu \mathrm{m}^{2}$ remaining after the partial digestion of organic matter are optically counted by automated image analysis and defined as charcoal, while the elemental carbon remaining after thermal and chemical oxidative treatments is quantified as black carbon (BC). The obtained pyrogenic carbon records from three sediment core-based case studies, (i) the Late Pleistocene equatorial Pacific Ocean, (ii) the midHolocene European Lake Lucerne, and (iii) the Late Holocene African Lake Masoko, are interpreted as proxy records of regional transportation mechanisms and biomass burning activities. The results show that the burial of dark carbon-rich particles in the $360 \mathrm{kyr}$-long record from the west equatorial Pacific is controlled by the combination of sea-level changes and low-latitude atmospheric circulation patterns (summer monsoon dynamics). However, the three fold increases in charcoal and BC sediment influxes between 53-43 and $12-10$ kyr BP suggest that major shifts in fire activity occur synchronously with human colonization in the Indo/Pacific region. The coarse charcoal distribution from a $7.2 \mathrm{kyr}$ record from Lake Lucerne in Switzerland closely matches the regional timing of major technical, land-use, and socio-economic changes during the Neolithic (between ca. 5.7 and $5.2 \mathrm{kyr}$ BP and 4.9-4.5 kyr BP), the Bronze and Iron Ages (at ca. 3.3 and $2.4 \mathrm{kyr} \mathrm{BP}$, respectively), and the industrialization (after AD 1838), pointing to the key impact of human activities on the sources, transportation processes and reservoirs of refractory carbon during the Holocene. In the tropical Masoko maar lake in Tanzania, where charcoal and BC records are highly sensitive to the local climate and environment, surface runoffs from forested areas and/or aerial transportation over short distances are also important sources for detrital charred particles. However, this $4.3 \mathrm{kyr}-$ long record exhibits a major increase in charcoal and BC sediment influxes between 1.8 and $0.6 \mathrm{kyr} \mathrm{BP}$, synchronously with the regional extent of Late Iron Age and agricultural innovations. Therefore, in both marine and terrestrial depositional environments, the climate- and vegetation-controlled fire regimes appear to be strongly associated to societal changes, or directly affected by human practices. In fact, the anthropogenic effect associated to past human activities (e.g. settlement, agriculture, and metallurgy) has temporarily at least tripled the emissions of pyrogenic carbon in the environment. However, the data from the three Late Pleistocene to Holocene sequences also show that the redistribution of fossil particles by runoff and erosion processes is a significant source of pyrogenic carbon that should be understood as a prerequisite for interpreting sedimentary records of biomass burning.
\end{abstract}

() 2010 Elsevier B.V. All rights reserved.

\footnotetext{
* Corresponding author.

E-mail address: Florian.Thevenon@yahoo.fr (F. Thevenon).
}

\section{Introduction}

Despite their major environmental and climatic effects, the dynamics of vegetation fires as well as the anthropogenic impact on fire regimes are still poorly understood for the present and documented for the past (Power et al., 2007). In fact, the determination of 
combustion-derived products in sedimentary archives is a key issue for reconstructing past fire-regime dynamics and aerosol fallout through time, and for further improving quantification and understanding of global carbon budgets (Marlon et al., 2008; Conedera et al., 2009).

Although the propagation of fires depends on a variety of natural climatic, ecologic or geomorphologic factors, there is a major contribution of humans to the ignition of present-day fires (Goldammer 1993). This human impact is particularly significant in the tropics (Dickson et al., 2006), where fires are used to clear or exploit the forests, to brush the land (control of weeds, shrubs, tree seedling, and litter accumulation), or to manage grazing lands (Fig. 1). Fires are also widely used for agricultural purposes (burning agricultural wastes and increasing nutrients available for uptake by plants), and for producing charcoal for industrial and domestic uses (traditional metalworking or brick making, cooking and heating). The applications of fire in land-use changes and wildfires are especially widespread in tropical regions that are at least seasonally or episodically dry (Andreae 1991). The intensity of the fire is mainly determined by the accumulation rate of dry plant matter (i.e. the amount of available fuel) and fire frequency. However, many examples demonstrate that human colonization is almost everywhere marked by an initial increase in residues of vegetation fires, and that the alteration of fire regimes is a ubiquitous feature of social change (Pyne and Goldammer 1997). Because natural fires mostly occur when the fuel combustible is dry, while most human fires are ignited while the fuel combustible is moist, a shift from natural to anthropogenic-driven fire regime can double or even triple trace-gas emissions (Saarnak, 2001).

Vegetation fires produce large amounts of trace gases and aerosol particles that play important roles in present-day atmospheric chemistry and climate (Crutzen and Andreae, 1990; Andreae et al., 2005). Due to their resistance to biochemical degradation in soils and sediments, the long-lived combustion-derived solid products represent a sink for the fast atmospheric-biospheric carbon cycle (Kuhlbusch and Crutzen, 1996), but their contribution in the global carbon cycle and

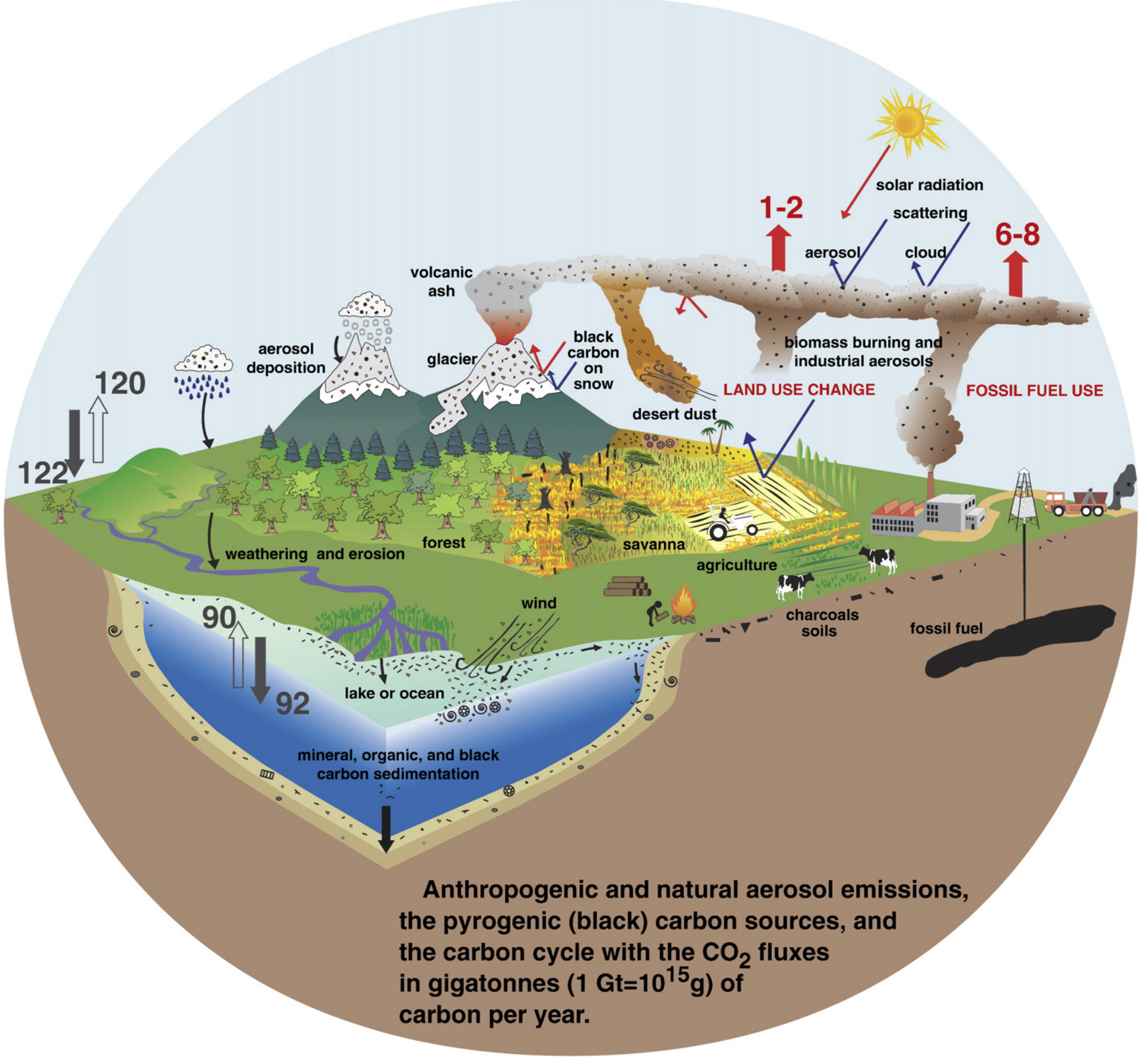

Fig. 1. A schematic drawing of the pyrogenic (black) carbon sources, and the carbon cycle. 
their temporal distribution in sediments are still poorly understood (Suman et al., 1997). More specifically, the composition and sources of pyrogenic carbon and its changing influx through time remain uncertain, a complication arising from the lack of standardized methodology, and the resulting uncertainty in identifying and quantifying such variables in the environment (Chameides and Bergin, 2002). To date, there is no standard protocol and terminology for determining the residues of combustion, and inter-laboratory analyses of sedimentary combustion-derived products largely differ with the various analytical techniques, which measure different pyrogenic materials with widely contrasting physicochemical properties (Countess, 1990). Based on the analysis of characteristic lacustrine and marine sedimentary records, this study aims to propose a reliable experimental definition of charcoal and elemental black carbon (BC), in order to reliably quantify pyrogenic carbon in the environment and in different sedimentary archives. To improve the quantification of the pyrogenic carbon in sedimentary archives, a combination of two new methods has been developed, that counts the charcoals by automated image analysis, whereas BC is quantified by elemental carbon analysis after thermal and chemical oxidative treatments.

\section{State of knowledge}

\subsection{Biomass and fossil-fuel combustion impact on present-day climate}

Land-use change and fossil-fuel use release today about 1-2 and $6-8 \mathrm{GtC} \mathrm{yr}^{-1}\left(10^{15} \mathrm{~g}\right.$ carbon per year) of net carbon dioxide $\left(\mathrm{CO}_{2}\right.$, which is the most important anthropogenic greenhouse gas) in the atmosphere, respectively, together with large amounts of particulate aerosols (IPCC, 2007 ; Canadell et al., 2007; Fig. 1). Although the oceans and the terrestrial biosphere currently absorb about half of the $\mathrm{CO}_{2}$ that is emitted by biomass and fossil-fuel combustion (Fig. 1), these releases make an important contribution to present-day atmospheric chemistry and climate (Crutzen and Andreae, 1990).

In addition to $\mathrm{CO}_{2}$, a large variety of gases and particles are emitted from biomass and fossil-fuel combustion processes. The atmospheric particulate matter is mainly in the form of BC-aerosols, and anthropogenic contributions to natural aerosol emissions ( such as sea salt, desert dust and volcanic ash; Fig. 1) modify the Earth's climate by decreasing the solar radiation reaching the surface (Penner et al., 1992; Andreae et al., 2005; Fig. 1). Moreover, BC-aerosols also affect the large-scale circulation and the hydrologic cycle (through cloud lifetime and precipitation) with significant effects on regional climate (Menon et al., 2002), while land-cover changes and deposition of BC-aerosols on snow are contributing to the combined radiative forcing (IPCC, 2007; McConnell et al., 2007; Fig. 1).

\subsection{Definition of the combustion products}

A result of the lack of common terminology and experimental definition of the combustion products is that ambiguous terms are applied to the particles originating from combustion processes, and large analytical discrepancies yield very different estimates of pyrolysed carbon (Currie et al., 2002; Elmquist et al., 2004). In fact, a clear discrimination between combustion-derived products and some natural refractory organic compounds is generally difficult to obtain (Novakov et al., 1997). This is particularly true for sedimentary environments, where the deposition and preservation of highly oxidation-resistant compounds (e.g. soil-originating humic acids, bacterially-originating organic carbon) are influenced by climatic and environmental changes (erosion or runoff processes, lake or sea-level changes). Consequently, the main difficulty in extracting particulate products of combustion in sedimentary archives is to ensure the complete removal of unburned organic matter (Bradbury, 1997).

In order to better define the combustion products, a combustion continuum model (Fig. 2) has been proposed by Masiello (2004). This

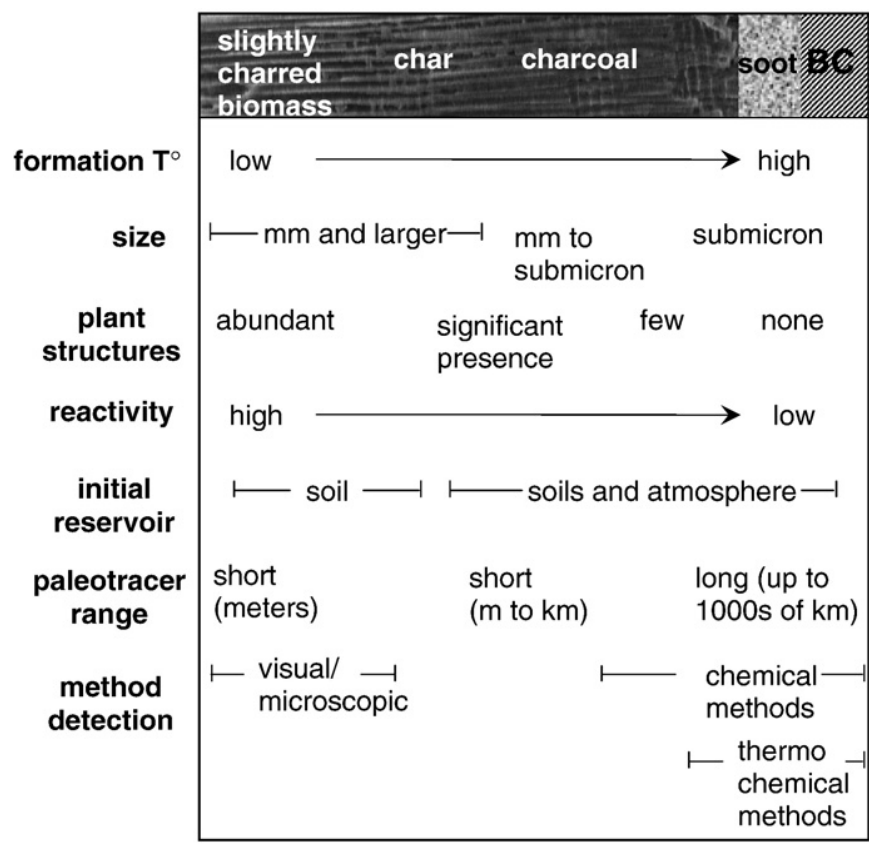

Fig. 2. The pyrogenic carbon combustion continuum and the corresponding techniques of quantification (modified from Masiello, 2004).

model describes the combustion products and the associated methodological approach as a continuum. Charring processes refer to the generation of particulate pyrogenic products and depend on the type of plant-derived material and the degree of combustion. Charcoal particles (sub- $\mu \mathrm{m}$ to several mm-sizes) are produced at low temperatures retaining recognizable anatomic structures (Jones et al., 1997; Fig. 2). The smallest particles can be carried out with smoke emissions while large charcoal particles have a very short-range transport (Clark and Patterson, 1997) (Fig. 2). BC and soot particles ( $\leq 1 \mu \mathrm{m}$ ) are formed at higher degrees of combustion as fire-altered material or produced via gas phase processes, therefore encompassing a complex mixture of organic matter along with pure BC (Cachier et al., 1989). Most of the firederived particulate carbon emitted to the atmosphere is in the sub- $\mu \mathrm{m}$ size range, and is either degraded under poorly understood conditions or trapped into natural archives (e.g. sediment, peat, or ice deposits), depending on atmospheric transport (wind velocity and direction), wash-out, and depositional processes (Fig. 1).

\subsection{Analysis of the pyrogenic carbon}

Considering that the response of the charred carbon to the experimental extraction depends on the degree, to which the precursor plant material has been carbonized, and also on the oxidative treatment (Bird and Gröcke, 1997), the nomenclature of the charred particulate material has to be primarily defined by physical and chemical analytical properties that do not univocally refer to combustion processes. The plant-derived material partially altered and blackened by fire is generally referred as charcoal by microscopic characteristics (Clark, 1988). Optical techniques have been developed to study the anatomic structure of the plant-derived material and to count microscopic charcoal particles (Clark, 1984) by using incident or transmitted light microscopes (Fig. 2). However, the preparation of the pollen slides, as used for manual counting, generally restricts the analysis of confident charcoal to diameters larger than $10 \mu \mathrm{m}$ (i.e. relatively coarse aerosol assemblage), failing to detect the submicron carbonaceous aerosols as well as the charcoal degradation products. Therefore, traditional optical microscope measurements of charcoal are not sensitive to detect the radiative effects of biomass burning and the regional biomass burning history (Masiello, 2004). 
In contrast, the charcoal determination used in this study is based on the automated counting of the dark particles $>0.2 \mu \mathrm{m}^{2}$ as isolated by the image analysis of microscopic slides, and thereby focuses on a large window of the combustion continuum (Fig. 2). Details on the method are found in Thevenon et al. (2003). To remove the labile (non-resistant) organic material and minimize particle fragmentation, the oxidative treatments (hydrogen peroxide and nitric acid) are applied without any rinsing/centrifugation steps. The remaining dark particles are isolated by thresholding the gray-level of the binary images (black and white images). The black particles are automatically counted and the results are expressed in charcoal area per gram of dry sediment $\left(\mathrm{mm}^{2} \mathrm{~g}^{-1}\right)$ and converted in charcoal influx $\left(\mathrm{mm}^{2} \mathrm{~cm}^{-2} \mathrm{yr}^{-1}\right)$. Lacking automated micro-charcoal recognition analysis, a major requirement for the application of the current method is to ensure that the contribution of non-charcoal opaque minerals (e.g. basaltic obsidian shards, iron monosulfides, sand) to the distribution of dark particles is negligible. Afterwards, an optical observation of pilot samples containing sedimentary charcoal is performed for choosing the most appropriate threshold value. In the absence of dry density measurements, we used the available wet bulk density values for the calculation of the accumulation rates.

The $\mathrm{BC}$ remaining after oxidative treatment(s) is generally quantified by elemental carbon analysis using infrared spectroscopy, coulometric titration, or gas chromatography. Thermal oxidative treatments at $340-375{ }^{\circ} \mathrm{C}$ are generally used to remove organic matter and to extract atmospheric fire-originating $\mathrm{BC}$, which remains non-volatile (Cachier et al., 1989). Similarly, the thermal inertness of the fire-altered material is used to discriminate soot-BC from other organic sedimentary compounds (Gustafsson et al., 1997). However, the separation between organic carbon and $\mathrm{BC}$ by a single thermal treatment is tedious with sedimentary environments containing a wide range of terrestrial refractory materials (Nguyen et al., 2004). Hence, different chemical methods are used to extract BC, after removing natural organic components with hydrogen peroxide (Smith et al., 1973; Emiliani et al., 1991), hot nitric acid (Winkler, 1985; Verardo, 1997), or sulfodichromate solution (Wolbach and Anders, 1989). As a matter of fact, further experiments have demonstrated that the combination of thermal and chemical oxidative treatments provides more valuable proxies of the combustion/pyrolysis of terrestrial plant material preserved in sedimentary environments (Kuhlbusch, 1995; Middelburg et al., 1999; Gelinas et al., 2001; Thevenon et al., 2004). The thermal and thermo-chemical methods, however, only detect the most refractory BC fractions, failing to yield any information about local biomass burning history, as these techniques do not detect the part of the combustion continuum with a short paleotracer range (i.e. the slightly charred biomass which is degraded by the oxidative treatment; Fig. 2).

In this study, the method used for the BC analysis follows Thevenon et al. (2004). The extraction of BC from other sedimentary compounds combines a chemical oxidative treatment (dichromate oxidation procedure and hydrogen peroxide) subsequent to a thermal oxidative treatment $\left(375^{\circ} \mathrm{C}\right.$ during $24 \mathrm{~h}$ ). This approach allows to remove any artificially charred organic matter formed during the thermal treatment, while the resulting $\mathrm{BC}$ is eventually left for elemental analysis (detection limit of ca. $2.3 \mu \mathrm{g}$ carbon). Finally, the BC concentration (\% weight) is converted to BC influx ( $\mu \mathrm{g} \mathrm{cm}{ }^{-2} \mathrm{yr}^{-1}$ ). This method has been tested using carbonaceous standards (Thevenon, 2003): the labile carbon (Acetanilide, SRM No. 141c) and the charred carbon (industrial willow charcoal) standards were completely removed by the thermal treatment, while only $30 \%$ of the resistant carbon standard (Aldrich humic acids) was oxidized. However, most of this refractory carbon was removed by the combined thermo-chemical procedure (remaining humic acids carbon $<2 \%$ ), indicating that only the ultimate terms of combustion can be properly analyzed with this method. Lithogenic (Alibert mine, Siberia) and synthetic (CAS No. 7782-42-5) graphite standards were eventually used to reproduce the behavior of an extremely refractory form of BC (anthropogenic graphitic BC, Dickens et al., 2004), and to estimate the recovery of the method (mean recovery of $83 \%, \mathrm{SD}=9, n=26$ ). Further tests using a soot reference material (N-Hexane) have demonstrated that the automated optical technique can be calibrated with the thermo-chemical procedure, and that both methods allow reproducible microgram-level carbon determination from sediment and ice core records (Thevenon et al., 2009).

\section{Oceanic and continental pyrogenic carbon records}

\subsection{West equatorial pelagic Pacific Ocean}

A cored sequence (MD97-2140) spanning the last $360 \mathrm{kyr}$ was collected from the Eauripik ridge in the Caroline Basin $\left(2^{\circ} \mathrm{N}, 141^{\circ} \mathrm{E}\right.$; $2547 \mathrm{~m}$ water depth). Charcoal and BC records show a roughly similar pattern of fluctuations over the last $360 \mathrm{kyr}$ (Fig. 3), consistently reflecting the regional emission of smoke carbonaceous particulate material and biomass burning activity. The total charcoal influx ranges from less than 0.001 to $0.05 \mathrm{~mm}^{2} \mathrm{~cm}^{-2} \mathrm{yr}^{-1}$, while the $\mathrm{BC}$ influx ranges from 0.08 to $5.04 \mu \mathrm{g} \mathrm{cm}^{-2} \mathrm{yr}^{-1}$. The mean and maximum values for charcoal and BC influxes are reported in Table 1, accounting for about $0.01 \mathrm{~mm}^{2} \mathrm{~cm}^{-2} \mathrm{yr}^{-1}$ and $0.76 \mu \mathrm{g} \mathrm{cm}^{-2} \mathrm{yr}^{-1}$, respectively. The comparison of the charcoal record with the documented quantitative data set is difficult, due to large differences in charcoal quantification methods and to the difficulty to count small charcoal particles with traditional microscopic techniques. However, the MD97-2140 BC influx is consistent with previously reported values from north Pacific pelagic sites, ranging from 0.001 to $3.6 \mu \mathrm{BCC} \mathrm{cm}^{-2} \mathrm{yr}^{-1}$ (Herring, 1985). Such values are slightly higher than (i) BC influxes reported by Smith et al. (1973) for pelagic sediments from Pacific and Atlantic Oceans (0.002 to $0.2 \mu \mathrm{gBC} \mathrm{cm}^{-2} \mathrm{yr}^{-1}$ ) and (ii) the BC influx measured by Dickens et al. (2004) in the central equatorial Pacific $\left(0.48 \mu \mathrm{gBC} \mathrm{cm}^{-2} \mathrm{yr}^{-1}\right)$. Such differences could be explained by the distance of the site studies from continents (ca. $400 \mathrm{~km}$ for core MD97-2140 and ca. $3000 \mathrm{~km}$ for other sites). Indeed, $\mathrm{BC}$ influxes tend to decrease from the areas adjacent to continents toward the center of the Pacific (Suman et al., 1997).

The first outcome of this study is that the charcoal and BC influxes records are strongly controlled by global and regional climate dynamics (Thevenon et al., 2004). In fact, a significant part of the dark carbon-rich particles (including petrogenic BC; Dickens et al. 2004) is likely stored in hemipelagic areas prior to further transportation during low sea-level periods. That is the reason why the charcoal record is partially influenced by the indirect effect of glacial-interglacial changes in ice volume and sea level. However, the detail analysis of the BC and charcoal signals consistently reflect the characteristic periodicities of the East Asian summer monsoon dynamics and the competing forcings of glacial/interglacial and long-term El Niño-Southern Oscillation (ENSO)like climatic patterns (see details in Thevenon et al., 2004). The deposition of dark carbon-rich particles in the west pacific area then appears significantly constrained by low-latitude atmospheric circulation patterns, i.e. by the intensity of the East-Asian winter monsoon which variability is today connected to ENSO.

Last but not least, the MD97-2140 pyrogenic carbon record shows two major three-fold increases during Late Pleistocene and Early Holocene periods, at ca. 53-43 kyr and ca. 12-10 kyr BP, respectively (Fig. 3). The first increase occurs just after the earliest major migration of Homo sapiens to Sahul (Australia and Papua New Guinea joined when sea level was lower) ca. 60-50 kyr (Roberts et al., 1994). The precise cause of the 53-43 kyr event is still elusive and may obviously point to an indirect linkage between outstanding fire activity in the region and a major episode of human migration in the area. However, considering that a shift from natural to human-driven fire regime may triple the emissions of non- $\mathrm{CO}_{2}$ gases (because the fire activity increases while the burning efficiency of the fire decreases; Saarnak, 2001), the 53-43 kyr three-fold increase in dark carbon-rich particles strongly suggests an impact of human 


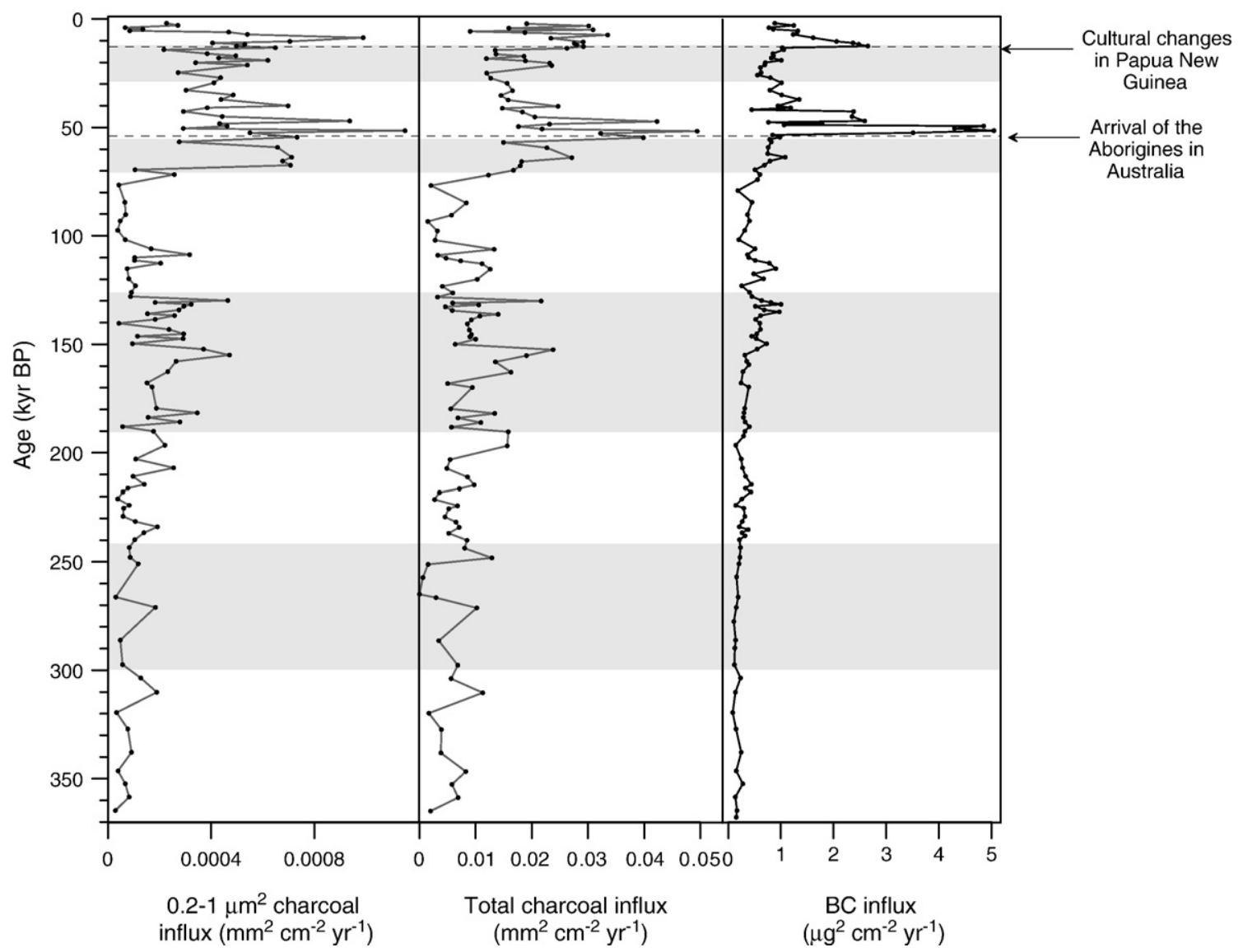

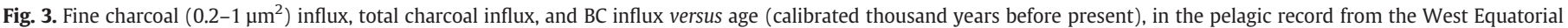
Pacific (core MD97-2140). Shaded areas indicate the glacial periods, unshaded areas indicate interglacial periods.

migration or new developments in technology (e.g. fire-stick farming of the Australian Aborigines), in association with the natural dynamics of fire frequencies and high ENSO activity (Kershaw et al., 1997; Kershaw et al., 2003). The second three-fold increase in the amplitude of the dark carbon-rich particles around 12-10 kyr likely occurs during or immediately after the northern hemisphere cold Younger Dryas event. Strikingly, this second high-amplitude peak also coincides with changes in human practices in Papua New Guinea. Indeed, archeological data show that a number of occupation sites in highland environments increased considerably between 15 and $10 \mathrm{kyr}$ BP, slightly earlier than the spread of agricultural innovations in lowland Papua New Guinea (Hope and Tulip, 1994; Haberle, 1998).

Table 1

Mean (and maximum) values of the charcoal $\left(0.2-1 \mu \mathrm{m}^{2}\right.$, and total fractions) and the BC influxes for the studied sedimentary records.

\begin{tabular}{lcll}
\hline & $\begin{array}{l}0.2-1 \mu \mathrm{m}^{2} \\
\text { Charcoal influx } \\
\left(\mathrm{mm}^{2} \mathrm{~cm}^{-2} \mathrm{yr}^{-1}\right)\end{array}$ & $\begin{array}{l}\text { Total } \\
\text { Charcoal influx } \\
\left(\mathrm{mm}^{2} \mathrm{~cm}^{-2} \mathrm{yr}^{-1}\right)\end{array}$ & $\begin{array}{l}\text { Mean BC influx } \\
\left(\mu \mathrm{cm}^{-2} \mathrm{yr}^{-1}\right)\end{array}$ \\
\hline $\begin{array}{c}\text { West Equatorial } \\
\text { pelagic Pacific } \\
\begin{array}{c}\text { Lake Lucerne } \\
(\text { Central Switzerland) }\end{array}\end{array}$ & $0.001(0.001)$ & $0.013(0.049)$ & $0.76(5.04)$ \\
$\begin{array}{c}\text { Lake Massoko } \\
\text { (East Africa) }\end{array}$ & $0.039(0.143)$ & $7.386(24.312)$ & $6.45(18.42)$ \\
\hline
\end{tabular}

a Data prior to AD 1838.

\subsection{Lake Lucerne (Central Switzerland)}

A short gravity core (4WS05-S1) and a long piston core (4WS00-1P) have been retrieved from a sub-basin of Lake Lucerne, Switzerland $\left(47^{\circ} \mathrm{N}, 8^{\circ} \mathrm{E} ; 434 \mathrm{masl}\right.$; lake area is about $\left.116 \mathrm{~km}^{2}\right)$ located in Central Europe. Before the industrial revolution in the area (AD 1838), the influx of the fine charcoal fraction $\left(0.2-1 \mu \mathrm{m}^{2}\right)$ ranges from 0.04 to $0.20 \mathrm{~mm}^{2} \mathrm{~cm}^{-2} \mathrm{yr}^{-1}$, and the total charcoal influx from 3.35 to $16.11 \mathrm{~mm}^{2} \mathrm{~cm}^{-2} \mathrm{yr}^{-1}$ (Fig. 4). During the nineteenth-century, a great increase in charcoal influx occurs (total charcoal influx $>17 \mathrm{~mm}^{2} \mathrm{~cm}^{-2} \mathrm{yr}^{-1}$ ). This corresponds precisely to the period of steamboat navigation on Lake Lucerne, with a maximum at AD 1900 due to the coal combustion $\left(33.33 \mathrm{~mm}^{2} \mathrm{~cm}^{-2} \mathrm{yr}^{-1}\right)$. The successive burning of wood (AD 1838), coal (AD 1862), and diesel (AD 1931) by the steamboats has produced specific fly-ash particles (Fig. 5), thereby providing, for the first time in a Swiss Lake, valuable chronologic markers for dating the recent sediments (see details in Thevenon and Anselmetti 2007; Griffin and Goldberg, 1981).

Before the industrial revolution, the mean influx values for fine and total charcoal fractions range between 0.11 and $9.01 \mathrm{~mm}^{2} \mathrm{~cm}^{-2} \mathrm{yr}^{-1}$, respectively (Table 1 ). The charcoal input is primarily linked to redistribution of detrital $\mu$ m-size charcoal degradation products from surface runoff into the large lake basin (Thevenon and Anselmetti, 2007). However, the coarse charcoal-particle distribution shows three prehistoric periods of regional enhanced fire activity ( $>38 \mu \mathrm{m}$ charcoal influx $>^{1} 0.15 \mathrm{~mm}^{2} \mathrm{~cm}^{-2} \mathrm{yr}^{-1}$ ), centered on the human cultural transitions of the Middle/Younger Neolithic (5550 BP), the Early/Late Bronze Age (3300 BP), and the First/Second Iron Age (2400 BP) (Fig. 4). These prehistoric periods of human impact in Central Switzerland indicate a striking synchronicity not only with the major documented socio-cultural changes and the regional fire history (Tinner et al., 2003), 


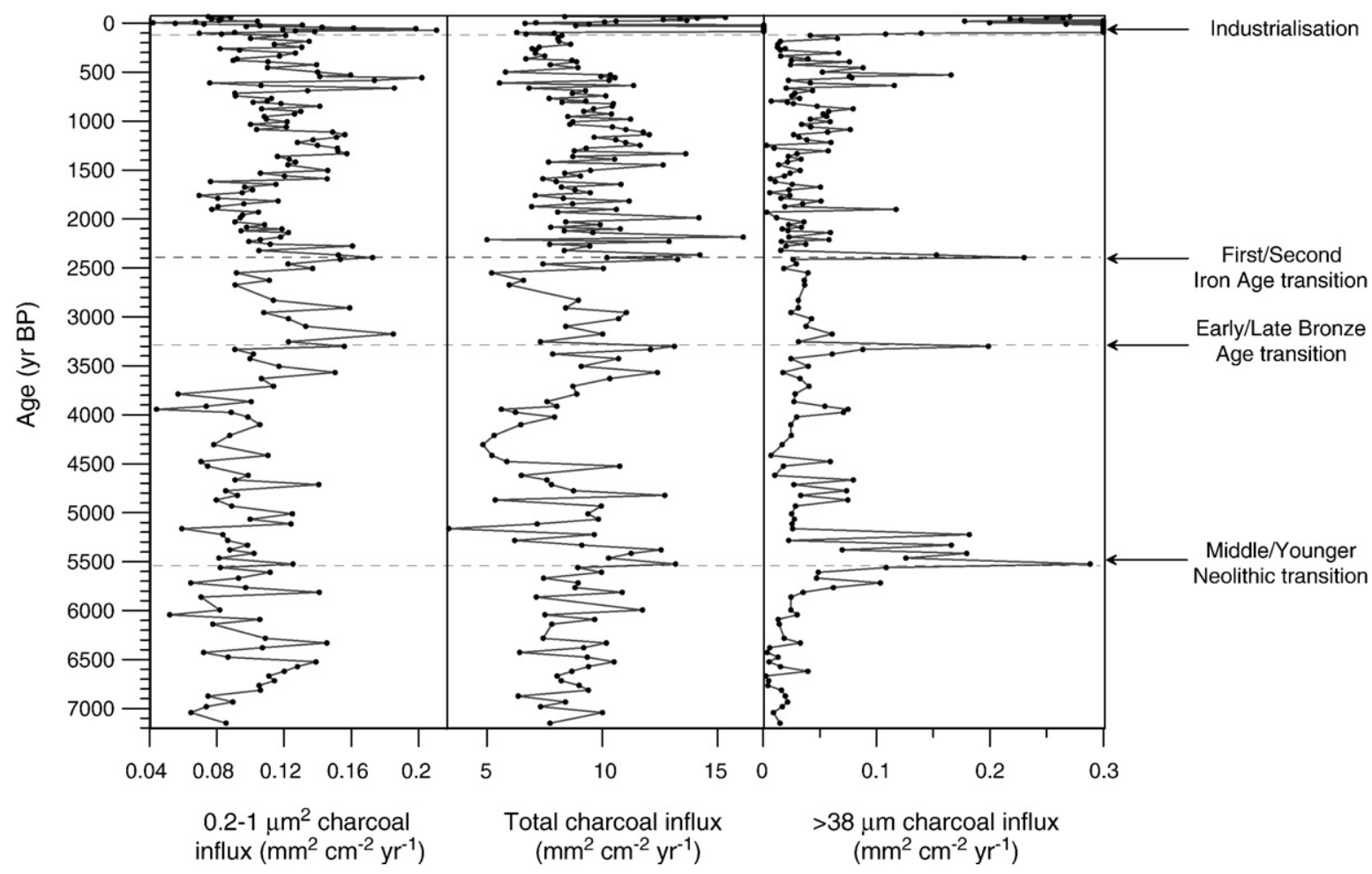

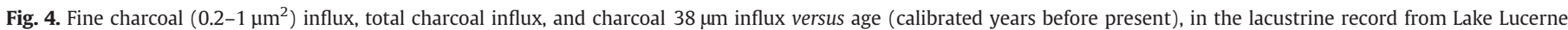
(Central Switzerland; cores 4WS00-1P and 4WS05-S1).

but also with periods of global climate cooling and regionally unstable climate (Magny and Haas, 2004). These results could therefore suggest that, most probably, unstable environmental conditions influenced human settlement patterns in the Swiss Plateau together with land-use changes or technological and social innovations.

\subsection{Lake Masoko (Tanzania)}

A mackereth core (MM8) spanning the last $4.3 \mathrm{kyr}$ BP was collected from lake Masoko $\left(9^{\circ} \mathrm{S}, 33^{\circ} \mathrm{E} ; 770 \mathrm{masl}\right.$; lake area is about $\left.0.5 \mathrm{~km}^{2}\right)$, a small maar lake from southern Tanzania where surrounding Miombo environments point to a sustained activity of biomass fires. Paleoenvironmental studies from this site indicate that erosional and depositional processes, which partly include the transportation and deposition of dark carbon-rich particle assemblages, have been highly sensitive to aridity and to the amplitude of lake oscillations at seasonal to decadal scales (Williamson et al., 1999; Garcin et al., 2006). Surface erosion from locally burnt woodland soils, as well as charcoal transportation in the atmosphere over short distances therefore constitutes two competing processes for coarse charcoal transportation to the lake.

The influx of the fine charcoal fraction $\left(0.2-1 \mu \mathrm{m}^{2}\right)$ ranges from 0.01 to $0.14 \mathrm{~mm}^{2} \mathrm{~cm}^{-2} \mathrm{yr}^{-1}$, and the total charcoal influx from 1.86 to $24.31 \mathrm{~mm}^{2} \mathrm{~cm}^{-2} \mathrm{yr}^{-1}$ (Fig. 6). The mean values for total charcoal and $\mathrm{BC}$ influxes are reported in Table 1, accounting for about $7.39 \mathrm{~mm}^{2} \mathrm{~cm}^{-2} \mathrm{yr}^{-1}$ and $6.45 \mu \mathrm{g} \mathrm{cm}^{-2} \mathrm{yr}^{-1}$, respectively. The tremendous and homogeneous BC and charcoal accumulation values during runoff/erosion events imply that tropical soil and lake sediments constitute a considerable reservoir for pyrogenic carbon. The results also point out that fine-refractory forms of carbon (charcoal $0.2-1 \mu \mathrm{m}^{2}$ and BC) may represent a relatively low contribution of the total charcoal storage (less than $1 \%$ for core MM8).

In addition to the control of runoff/erosion processes on charcoal and $\mathrm{BC}$ particles transportation to the lake, a rapid increase in charcoal and $\mathrm{BC}$ around $1.8 \mathrm{kyr} \mathrm{BP}$, synchronous with the rapid woodland degradation inferred from the pollen spectra (Vincens et al., 2003), likely reflects the interaction between climate, vegetation and fires. Such a peculiar three-fold increase of dark carbon-rich particles occurs during the onset of an interval of drier conditions in the region, as shown from a gradual decline in mountain forests and in water balance (Barker et al., 2000). It also suggests that, for a ca. $2 \mathrm{kyr}-$ long interval ending at ca. $2 \mathrm{kyr}$ BP, a steady state was reached between the forested area and the fire regimes. Although the occurrence of a climatic threshold at ca. 2 kyr BP should not be ruled out, this major change in fire activity coincides with the arrival of Iron Age Bantu speaking people in the Great Lakes region and with the beginning of Late Iron Age activities in the area (Mapunda and Burg, 1991). Wetclimate crops inherited from West Africa or acquired in the Great Lakes region, combined with iron implements, had allowed the Bantu to farm in areas of East Africa by clearing the forest efficiently (Hamilton et al., 1986; Philippson and Bahuchet, 1994-95). The threefold increase in dark carbon-rich particles at Masoko may therefore provide additional evidence for the human impact on fire regimes, as it is regionally associated with the spread of agricultural and metallurgical innovations in eastern Africa.

\section{Conclusions}

This review paper shows that combined optical and chemical methods allow to establish inter-comparative records of pyrogenic carbon storage in different paleoenvironmental archives, and to better decipher between transportation and biomass burning processes. Although further improvements in optical and chemical analyses are respectively required to (i) better identify and count large size distributions of charcoal-particle assemblages at time resolution closer to the single biomass fire event, and (ii) quantify more accurately the complex chemical signature of pyrolized carbon as emitted in the atmosphere, we demonstrate here that combining physical and chemical approaches provide independent and complementary ways to better assess the activity of biomass fires in the past. We show with 

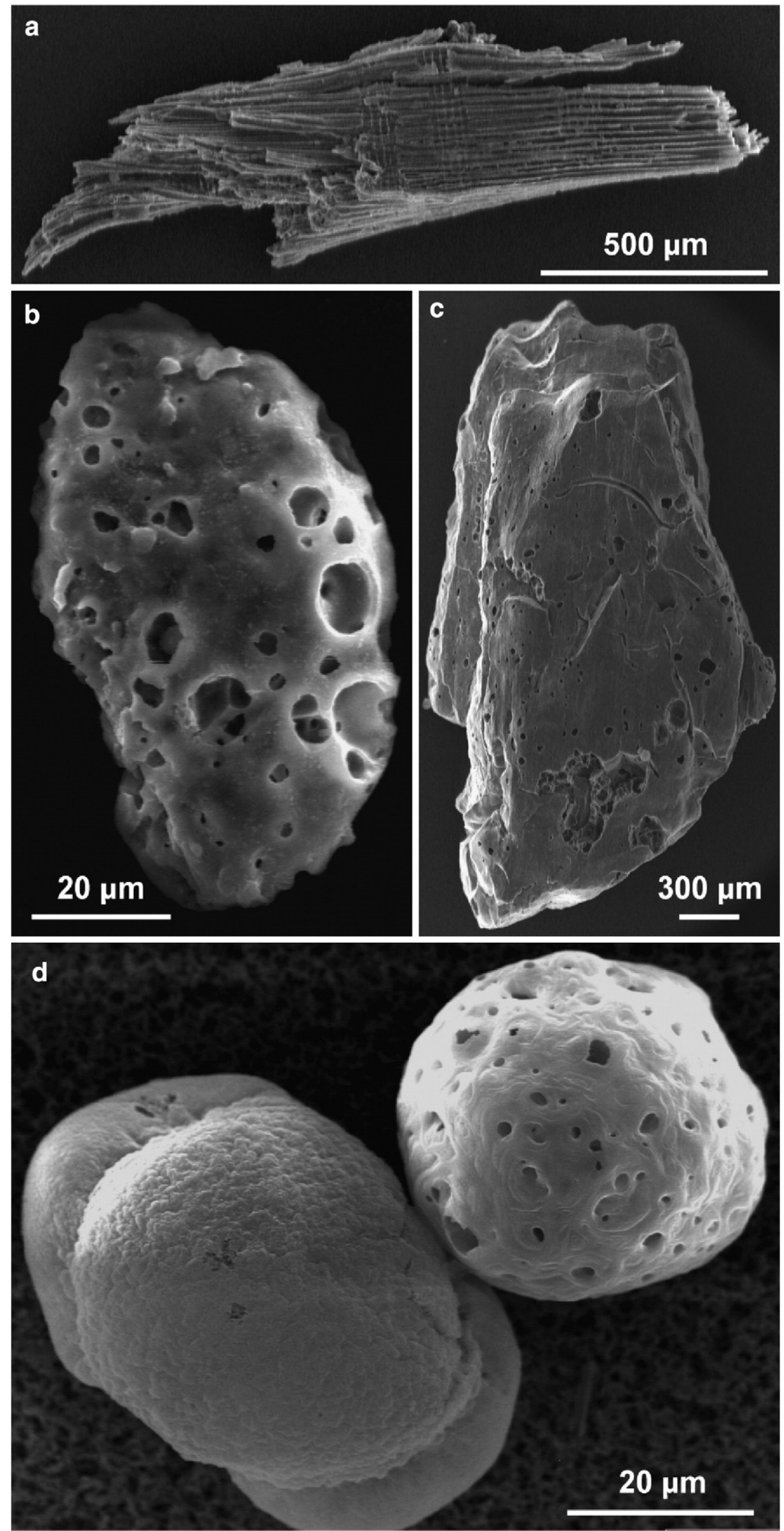

Fig. 5. Scanning electron micrographs of carbonaceous particles from the burning of wood (a), coal (b and c), and oil (d, right of the pine pollen) 


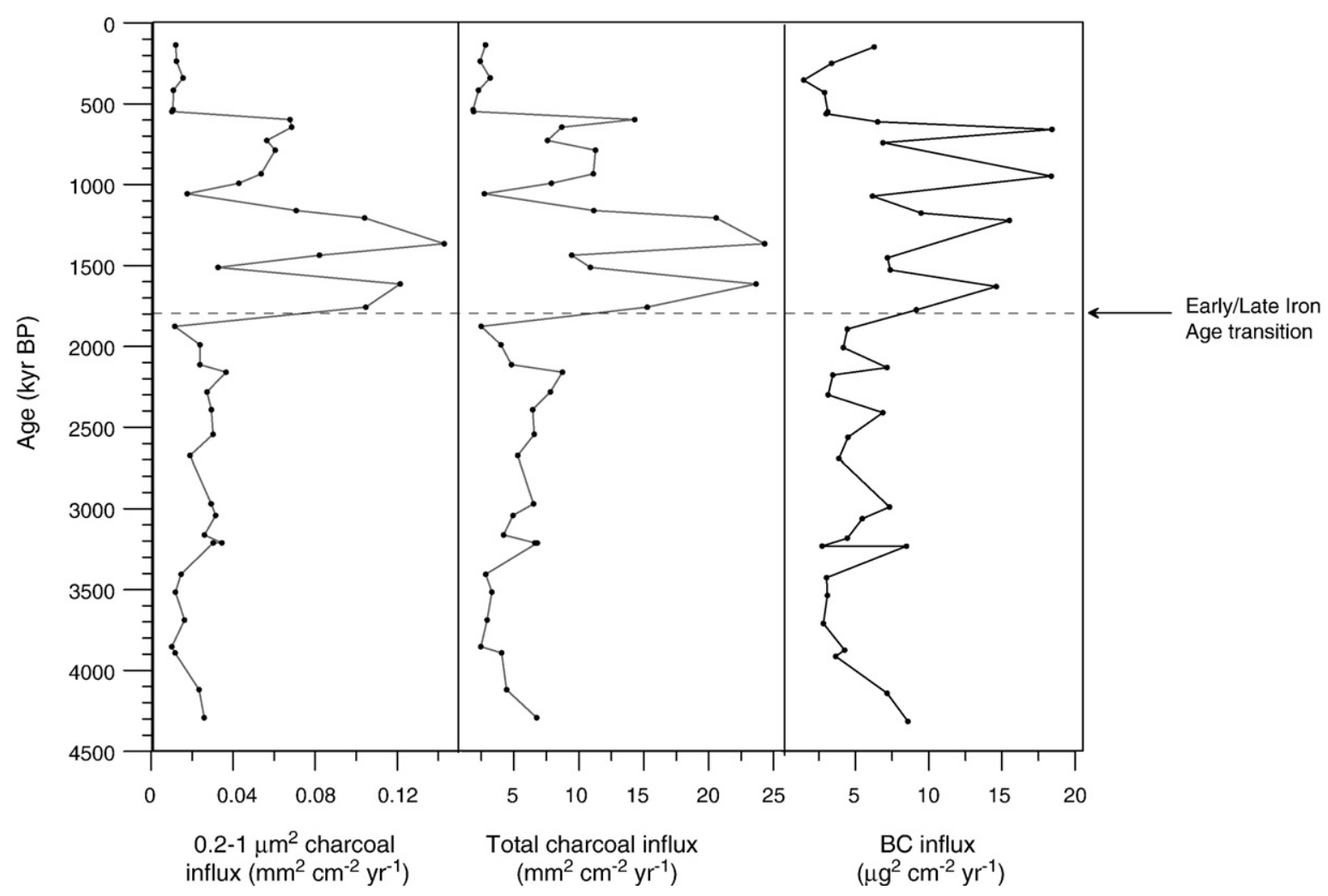

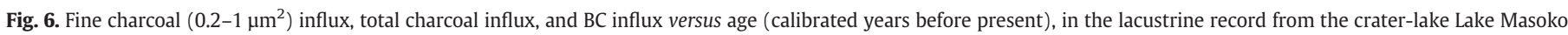
(SW Tanzania; core MM8).

three case studies that were investigated with the similar continuum method that:

(1) The redistribution of terrestrially-derived particles from the continental shelves and soils by runoff and erosion processes significantly influences oceanic and lacustrine charcoal/BC deposition. In lakes Masoko and Lucerne sediment cores, the total charcoal burial into sediments is largely superior to the fine-refractory forms of carbon (sub- $\mu \mathrm{m}$ charcoal and BC). Because continental sediments accumulate generally faster than pelagic sediments, the temporary storage of carbon by charcoal formation, accumulation in soils, and redistribution in lacustrine and coastal areas should therefore be reevaluated in global carbon cycle studies, especially for the tropics.

(2) The reconstructed input of dark carbon-rich particles from either biomass burning or sedimentary sources depends in the tropics on redistribution/deposition processes and natural fire frequencies, both controlled by monsoon dynamics and human impact on fire regimes (i.e. burning efficiency of the fires). Although the Lake Lucerne charcoal record also appears to be influenced from the redistribution of fossil charcoal and organic matter by surface runoff processes, the charcoal-size distribution technique allows to distinguish large-scale signals of biomass burning (i.e. peaks of coarse charcoal).

(3) Our three site studies show that the pyrogenic record, taken as a whole, is especially sensitive to the coupling between climate and anthropogenic changes. This is especially suggested from (i) the increases in amplitude of charcoal and BC peaks around 53-43 and $12-10 \mathrm{kyr}$ BP in the Indo-Pacific region, (ii) the striking synchronicity between Late Holocene to modern and Anthropocene charcoal peaks, climate change and major settlement or societal changes at the foot of the Swiss Alps, and (iii) the changes in fire regimes as associated to both drier conditions and settlement of Iron Age cultivators in southern Tanzania.
Finally, these results point to an urgent need to build data sets using calibrated analytical techniques that would improve the quantification of pyrogenic carbon storage and the understanding of biomass burning impact on the environment (e.g. vegetation, soils, and climatic forcing). The pyrogenic carbon influxes and reservoirs should be widely recognized and interpreted as a function of spatial and temporal scales in a variety of depositional environments (pelagic, coastal, lacustrine, peat, and ice). Furthermore, the sources, the transport mechanisms, and the potential impact of human activities must be considered to better assess the contribution of pyrogenic carbon influxes in the global carbon cycle.

\section{Acknowledgments}

We acknowledge the financial support of the INSU-ECLIPSE-CLEHA project and RESOLVE-ACI ecology quantitative programs, the IMAGES program, the French Ministry for Foreign Affairs (Lavoisier postdoctoral grant), and the Swiss National Science Foundation (SNSF Ambizione fellowship).

\section{References}

Andreae, M.O., 1991. Biomass burning: its history, use, and distribution and its impact on environmental quality and global climate. In: Levine, J.S. (Ed.), Global biomass burning: atmospheric, climatic, and biospheric implications. The MIT Press, Cambridge, MA, pp. 3-21.

Andreae, M.O., Jones, C.D., Cox, P.M., 2005. Strong present-day aerosol cooling implies a hot future. Nature 435, 1187-1190.

Barker, P., Telford, R., Merdaci, O., Williamson, D., Taieb, M., Vincens, A., Gilbert, E., 2000 The sensitivity of a Tanzanian crater lake to catastrophic tephra input and four millennia of climate change. The Holocene 10,303-310.

Bird, M.I., Gröcke, D.R., 1997. Determination of the abundance and carbon isotope composition of elemental carbon in sediments. Geochimica et Cosmochimica Acta 61, 3413-3423.

Bradbury, J.P., 1997. Reports of Working/Discussion Groups at NATO Workshop: sediment records of biomass burning and global change. In: Clark, J.S., Cachier, H., Goldammer, J.G., Stocks, B. (Eds.), Sediment Records of Biomass Burning and Global Change. Springer, Berlin, pp. 463-481. 
Cachier, H., Brémond, M.P., Buart-Ménard, P., 1989. Determination of atmospheric soot carbon with a simple thermal method. Tellus 41B, 379-390.

Canadell, J.G., Le Quere, C., Raupach, M.R., Field, C.B., Buitenhuis, E.T., Ciais, P., Conway, T.J. Gillett, N.P., Houghton, R.A., Marland, G., 2007. Contributions to Accelerating Atmospheric $\mathrm{CO}_{2}$ Growth from Economic Activity, Carbon Intensity, and Efficiency of Natural Sinks. . PNAS:0702737104.

Chameides, W.L., Bergin, M., 2002. Soot takes center stage. Science 297, 2214-2215.

Clark, R.L., 1984. Effects on charcoal of pollen preparation procedures. Pollen et spores XXVI, 559-576.

Clark, J.S., 1988. Particle motion and the theory of charcoal analysis: source area, transport, deposition, and sampling. Quaternary Research 30, 67-80.

Clark, J.S., Patterson, W.A., 1997. Background and local charcoal in sediments: scales of fire evidence in the paleorecord. In: Clark, J.S., Cachier, H., Goldammer, J.G., Stocks, B. (Eds.), Sediment Records of Biomass Burning and Global Change. NATO, Berlin, pp. 23-48.

Conedera, M. Tinner, W., Neff, C., Meurer, M., Dickens, A.F., Krebs, P., 2009. Reconstructing past fire regimes: methods, applications, and relevance to fire management and conservation. Quaternary Science Reviews 28 (5-6), 435-456.

Countess, R.J., 1990. Interlaboratory analyses of carbonaceous aerosol samples. Aerosol Science and Technology 12, 114-121.

Crutzen, P.J., Andreae, M.O., 1990. Biomass burning in the tropics: impact on atmospheric chemistry and biogeochemical cycles. Science 250, 1669-1677.

Currie, L.A., et al. , 2002. A critical evaluation of interlaboratory data on total, elemental, and isotopic carbon in the carbonaceous particle reference material NIST SRM 1649a. Journal of Research of the National Institute of Standards and Technology 107, 279-298.

Dickens, A.F., Gélinas, Y., Masiello, C.A., Wakeham, S., Hedges, J., 2004. Reburial of fossil organic carbon in marine sediments. Nature 427, 336-339.

Dickson, B.G., Prather, J.W., Xu, Y.G., Hampton, H.M., Aumack, E.N., Sisk, T.D., 2006 Mapping the probability of large fire occurrence in northern Arizona, USA. Landscape Ecology 21 (5), 747-761.

Emiliani, C., Price, D.A., Seipp, J., 1991. Is the postglacial artificial? The Geochemical Society 3, 229-231.

Elmquist, M., Gustafsson, Ö., Andersson, P., 2004. Quantification of sedimentary black carbon using the chemothermal oxidation method: an evaluation of ex situ pretreatments and standard additions approach. Limnology and Oceanograpy: Methods 2, 417-427.

Garcin, Y, Williamson, D. Taieb, M. Vincens, A, Mathe, P.E, Majule, A, 2006. Centennial to millennial changes in maar-lake deposition during the last 45, 000 years in tropical Southern Africa (Lake Masoko, Tanzania). Palaeogeography, Palaeoclimatology, Palaeoecology 239, 334-354.

Gelinas, Y., Prentice, K.M., Baldock, J.A., Hedges, J.I., 2001. An improved therma oxidation method for the quantification of soot/graphitic black carbon in sediments and soils. Environmental Science and Technology 35, 3519-3525.

Goldammer, J.G., 1993. Historical biogeography of fire: tropical and subtropical. In: Crutzen, P.J., Goldammer, J.G. (Eds.), Fire in the Environment: the Ecological, Atmospheric and Climatic Importance of Vegetation Fires. John Wiley and Sons, Chichester, pp. 297-314.

Griffin, J.J., Goldberg, E.D., 1981. Sphericity as a characteristic of solids from fossil-fue burning in Lake Michigan sediment. Geochimica et Cosmochimica Acta 45, 763-769.

Gustafsson, O., Haghseta, F., Chan, C., MacFarlane, J., Gschwend, P.M., 1997. Quantification of the dilute sedimentary soot phase: implications for PAH speciation and bioavailability. Environmental Science Technologies 31, 203-209.

Haberle, S.G., 1998. Late Quaternary vegetation change in the Tari Basin, Papua New Guinea. Paleogeography, Paleoclimatology, Paleoecology 137, 1-24.

Hamilton, A., Taylor, D., Vogel, J.C., 1986. Early forest clearance and environmenta degradation in south-west Uganda. Nature 320, 164-167.

Herring, J.R., 1985. Charcoal influxes into sediments of the North Pacific Ocean: the Cenozoic record of burning. In: Sundquist E.T., Broecker W.S. (Ed.), The Carbon Cycle and Atmospheric $\mathrm{CO}_{2}$ : Natural variations, Archean to Present. Amer Geophys Union, Washington DC, pp. 419-442.

Hope, G., Tulip, J., 1994. A long vegetation history from lowland Irian Jaya, Indonesia Paleogeography, Paleoclimatology, Paleoecology 109, 385-398.

IPCC (2007). Contribution of Working Group I to the Fourth Assessment Report of the Intergovernmental Panel on Climate Change Fourth Assessment Report, Climate Change 2007: The Physical Science Basis, Summary For Policymakers. www.ipcc.ch.

Jones, T.P., Chaloner, W.G., Kuhlbusch, T.A.K., 1997. Proposed bio-geological and chemical based terminology for fire-altered plant matter. In: Clark, J.S., Cachier, H., Goldammer, J.G., Stocks, J.G. (Eds.), Sediment Records of Biomass Burning and Global Change. Springer, Berlin, pp. 9-22.

Kershaw, A.P., Moss, P.T., van der Kaars, S., 1997. Environmental change and the human occupation of Australia. Anthropologie 35, 35-43.

Kershaw, A.P., van der Kaars, S., Moss, P.T., 2003. Late Milankovitch-scale climatic change and variability and its impact on monsoonal Australia. Marine Geology 201, 81-95.

Kuhlbusch, A.J., 1995. Method for determining black carbon in residues of vegetation fires. Environment Sciences and Technologies 29, 2695-2702.

Kuhlbusch, T.A.J., Crutzen, P.J., 1996. Black Carbon, the Carbon Cycle, and Atmospheric Carbon Dioxide. In "Biomass burning and global change". (J. S. Levine, Editor). MIT Press, Cambridge, Mass. pp. 160-169.

Magny, M., Haas, J.N., 2004. A major widespread climatic change around $5300 \mathrm{cal}$. yr BP at the time of the Alpine Iceman. Journal of Quaternary Science 19 (5), 423-430.
Mapunda, B., Burg, S., 1991. Preliminary report on archeological reconnaissance along the Ruhuhu river basin, Southern Tanzania. Nyame Akuma 36, 32-39.

Marlon, J.R., Bartlein, P.J., Carcaillet, C., Gavin, D.G., Harrison, S.P., Higuera, P.E., Joos, F., Power, M.J., Prentice, I.C., 2008. Climate and human influences on global biomass burning over the past two millennia. Nature Geoscience 1, 697-702.

Masiello, C.A., 2004. New directions in black carbon organic geochemistry. Marine Chemistry 92, 201-213.

McConnell, J.R., Edwards, R., Kok, G.L., Flanner, M.G., Zender, C.S., Saltzman, E.S., Banta, J.R. Pasteris, D.R., Carter, M.M., Kahl, J.D.W., 2007. 20th Century Industrial Black Carbon Emissions Altered Arctic Climate Forcing. Science 317 (5843), 1381-1384.

Menon, S., Hansen, J., Nazarenko, L., Luo, Y., 2002. Climate effects of black carbon aerosols in China and India. Science 297, 2250-2253.

Middelburg, J.J., Nieuwenhuize, J., van Breugel, P., 1999. Black carbon in marine sediments. Marine Chemistry 65, 245-252.

Novakov, T., Cachier, H., Clarck, J.S., Gaudichet, A., Macko, S., Masclet, P., 1997. Characterization of particulate products of biomass combustion. In: Clark, J.S., Cachier, H., Goldammer, J.G., Stocks, B. (Eds.), Sediment Records of Biomass Burning and Global Change. Springer, Berlin, pp. 117-143.

Nguyen, T.H., Brown, R.A., Ball, W.P., 2004. An evaluation of thermal resistance as a measure of black carbon in diesel soot, wood char, and sediment. Organic Geochemistry 35, 217-234.

Penner, J.E., Dickinson, R.E., O'Neill, C.A., 1992. Effects of aerosol from biomass burning on the global radiation budget. Science 256, 1432-1433.

Philippson, G., Bahuchet, S., 1994-95. Cultivated Crops and Bantu Migrations in Central and Eastern Africa: A Linguistic Approach, pp. 103-120. Azania 103-120.

Power, M.J., Marlon, J., et al., (2007). Changes in fire regimes since the Last Glacial Maximum: an assessment based on a global synthesis and analysis of charcoal data. Climate Dynamics. 30 (7-8), 887-907.

Pyne, S.J., Goldammer, J.G., 1997. The culture of fire: an introduction to anthropogenic fire history. In: Clark, J.S., Cachier, H., Goldammer, J.G., Stocks, J.G. (Eds.), Sediment Records of Biomass Burning and Global Change. Springer, Berlin, pp. 71-115.

Roberts, R.G., Jones, R., Nigel, A., Spooner, N.A., Head, M.J., Murray, A.S., Smith, M.A., 1994. The human colonization of Australia: optical dates of 53,000 and 60,000 years bracket human arrival at Deaf Adder Gorge, Northern territory. Quaternary Geochronology (Quaternary Science Reviews) 13, 575-583.

Saarnak, C.F., 2001. A shift from natural to human-driven fire regime: implications for trace-gas emissions. The Holocene 11, 373-375.

Smith, D.M., Griffin, J.J., Goldbreg, E.D., 1973. Elemental carbon in marine sediments: a baseline for burning. Nature 241, 268-270.

Suman, O., Kuhlbusch, T.A.J., Lim, B., 1997. Marine sediments: a reservoir for black carbon and their use as spatial and temporal records of combustion. In: Clark, J.S., Cachier, H., Goldammer, J.G., Stocks, B. (Eds.), Sediment Records of Biomass Burning and Global Change. Springer, Berlin, pp. 271-294.

Thevenon, F. (2003). Carbonaceous particles as proxies of past fire activity in intertropical lacustrine and marine sediments: methodological, climatic, and anthropic implications. PhD 03AIX30016, Université Aix-Marseille III.

Thevenon, F., Anselmetti, F., 2007. Charcoal and fly-ash particles from Lake Lucerne sediments (Central Switzerland) characterized by image analysis: anthropologic, stratigraphic and environmental implications. Quaternary Science Reviews 26, 2631-2643.

Thevenon, F., Williamson, D., Vincens, A., Taieb, M., Merdaci, O., Decobert, M., Buchet, G., 2003. A Late Holocene charcoal record from Lake Masoko, SW Tanzania: climatic and anthropologic implications. The Holocene 13 (5), 785-792.

Thevenon, F., Bard, E., Williamson, D., Beaufort, L., 2004. A biomass burning record from the West Equatorial Pacific over the last 360 kyr: methodological, climatic and anthropic implications. Paleogeography, Paleoclimatology, Paleoecology 213, 83-99.

Thevenon, F. Anselmetti, F.S., Bernasconi, S.M., Schwikowski, M., 2009. Mineral dust and elemental black carbon records from an Alpine ice core (Colle Gnifetti glacier) over the last millennium. Journal of Geophysical Research 114 (D17102), 1-11. doi:10.1029/ 2008JD011490.

Tinner, W. Lotter, A.F., Ammann, B., Conedera, M., Hubschmid, P., van Leeuwen, J.F.N. Wehrli, M., 2003. Climatic change and contemporaneous land-use phases north and south of the Alps 2300 BC to 800 AD. Quaternary Science Reviews 22 (14), 1447-1460.

Verardo, D.J., 1997. Charcoal analysis in marine sediments. Limnology and Oceanography 42 (1), 192-197.

Vincens, A., Williamson, D., Thevenon, F., Taieb, M., Buchet, G., Decobert, M., Thouveny, N., 2003. Pollen-inferred vegetation changes in Southern Tanzania during the last 4200 years: climate and/or human impact. Palaeogeography, Palaeoclimatology, Palaeoecology 198, 321-334.

Williamson, D., Jackson, M.J., Banerjee, S.K., Marvin, J., Merdaci, O., Thouveny, N., Decobert, M., Gibert-Masseau, E., Massault, M., Mazaudier, D., Taieb, M., 1999. Magnetic signatures of hydrological change in a tropical maar-lake (Lake Massoko, Tanzania): preliminary results. Physics and Chemistry of the Earth (A) 24 (9), 789-803.

Winkler, M.G., 1985. Charcoal analysis for paleoenvironmental interpretation: a chemical assay. Quaternary Research 23, 313-326.

Wolbach, W.S., Anders, E., 1989. Elemental carbon in sediments: determination and isotopic analysis in the presence of kerogen. Geochimica et Cosmochemica Acta 53, 1637-1647. 